S sciendo International Conference KNOWLEDGE-BASED ORGANIZATION
Vol. XXVII

\title{
EMPLOYMENT OF THE ARMED FORCES OF UKRAINE IN DIFFERENT PERIODS OF ANTI-TERRORIST OPERATION IN EASTERN UKRAINE
} (2014-2018)

\author{
Oleksandr SKRIABIN, Boris POPKOV, Inna VANOVSKA \\ "Taras Shevchenko" National University of Kyiv, Ukraine \\ skryabin07@meta.ua, boriska311@ukr.net, vanovskaya@ukr.net
}

\begin{abstract}
The article reviews issues related to the use of the Armed Forces of Ukraine in the antiterrorist operation (ATO) in eastern Ukraine (2014-2018), which became a form of repel and deterrence of Russian aggression, began in Crimea in February 2014 and subsequently continued in eastern regions of Ukraine. According to the nature and consequences of hostilities, the RussianUkrainian armed conflict is divided into initial and two main periods, within which a number of stages are defined, distinguished qualitatively in the nature and content of hostilities. The article shows how this affected the change of forms of the Armed Forces of Ukraine employment in the anti-terrorist operation. During the initial (Crimean) period, units and subdivisions of the Ukrainian army were not actually used to repel hybrid aggression of the Russian Federation, but later, when the Russian leadership began using a similar scenario of aggression in the eastern regions of Ukraine, the state responded with the armed fight. The authors believe that despite the swiftness of the first period, its events were characterized by frequent changes in the use of the Armed Forces of Ukraine - from patrolling and guarding important facilities to offensive, raid and search operations. The second period, according to the authors, was characterized by the conduct of the Ukrainian army's defensive actions with the active use of maneuvers in various dangerous areas.
\end{abstract}

Keywords: anti-terrorist operation, Armed Forces of Ukraine, Russian occupation forces, eastern Ukraine

\section{Introduction}

In the current conditions of the globalized world, the rapid development of communications, information technology, etc., there are new capabilities in resolving disputes between states to realize their own national interests. This has enabled some ambitious countries to carry out armed aggression using "hybrid" methods and mechanisms, which prioritize political, economic, advocacy measures, and the military means are used to as a force support instrument. This is confirmed by the events of the Russian-Ukrainian armed conflict, which began in 2014 and continues to this day. Ukraine has used security and defense forces to repel and deter Russian aggression. The form of their employment since 2014 has been the anti-terrorist operation, and since April 30, 2018 - the Joint Forces Operation (JFO). The Armed Forces of Ukraine played a key role in both operations.

In the recent history of Ukraine, its army had virtually no experience of large-scale combat operations, with the exception of a few units and subdivisions that participated in peacekeeping operations. Facing the armed aggression of the neighbouring country, whose military resources are among the 
strongest in the world in terms of strength and power, the Ukrainian armed forces have been gaining the most valuable combat experience for the eighth year in a row.

2. The purpose of the study - to show the activities of the Armed Forces of Ukraine during the anti-terrorist operation in eastern Ukraine through the historical prism of the events of the Russian-Ukrainian armed conflict.

\section{Applied methodology}

The methodological basis of the study was the general scientific principles of historicism, objectivity, system, specificity and the principle of dialectical unity of historical and logical domains, the use of which was taken as a basis in this work. Using the historical method of military confrontation, on the one hand we can identify the main and secondary events that influenced the course of hostilities, and on the other - to trace what forms of combat employment were undertaken by the parties to the conflict based on the current situation. A number of studies, varying in scope and form, have already been devoted to the description of the armed conflict in eastern Ukraine. In our opinion, the most perfect is the approach of military scientists, proposed in the publication "White Paper of the ANTI-Terrorist Operation in the Eastern Ukraine (20142016)" [1], where the historical periodization of the military conflict is introduced, dividing it into main periods and stages. This study uses the proposed approach to the historical periodization, extended it until the end of the operation, shows the specifics of the use of antiterrorist operation forces and in particular the Armed Forces of Ukraine in the confrontation with the aggressor.

\section{The main results of the study}

Even during the initial period of the Russian-Ukrainian armed conflict
(February 20 - early April 2014), its hybrid nature has already been demonstrated, when Russian troops occupied the territory of the Autonomous Republic of Crimea using non-standard methods for military science. The personnel of the military units of the Armed Forces of Ukraine were in fact deprived of the right to use weapons, as they were blocked by "allegedly peaceful local residents" with the support of units of the regular troops of the Russian Federation. At the same time, groups of Russian troops were deployed on Ukraine's borders, expecting an invasion of Ukraine in the event of an armed response. To prevent this, Ukraine did not carry out adequate armed resistance to the aggressive actions of regular Russian troops in Crimea, limiting itself merely to bringing its armed forces into full combat readiness.

The first period of the armed conflict (early April - September 5, 2014) is divided into three stages [1, p. 20].

The first stage (April-June 2014) is characterized by the active actions of the Russian special services to destabilize the situation in the eastern and southern regions of Ukraine, leading to the seizure of large areas of Donetsk and Luhansk regions by illegal armed formations (IAF). The leadership and basis of these units were Russian mercenaries who had combat experience in hot spots. To stabilize the situation, the Ukrainian leadership used the security and defense sector' forces in the form of an anti-terrorist operation.

The change in the understanding of the state leadership of the tasks of this operation gradually affected the format of involvement and participation of units and subdivisions of the Ukrainian army. At the beginning of the stage, they were used mainly as an auxiliary force to support the operation carried out by the law enforcement agencies. The personnel of the armed forces performed tasks on patrolling dangerous areas, guarding important state 
and military facilities, isolating places of accumulation of IAF.

However, the activities of law enforcement agencies as state structures in the fight against legally unregulated armed formations proved to be ineffective. In order to prevent the expansion of the crisis area, the import of weapons and ammunition from the territory of the Russian Federation, the creation of conditions for the functioning of the authorities, units of the Armed Forces of Ukraine isolated the crisis area by setting up checkpoints on important roads and communications. Operational build-up the of troops units provided control of the territory. It was necessary to deprive the sabotage and reconnaissance groups of the Russian mercenaries and its IAFs of the opportunity to carry out surprise attacks and organize sabotage at important sites in depth of Ukrainian troops. Control of the territory within the operational area was carried out by reconnaissance, regime, security and defense actions at the rear assets and communications [2, p. 94-95]. With proper fire support, extensive use of various ambushes, engineer constructions and maneuvers, relatively small forces could resist attacks and sabotage of Russian mercenaries.

During the second stage (July 1 - August 24, 2014), the Armed Forces of Ukraine together with the other anti-terrorist operation forces seized the combat initiative in the confrontation with the Russian mercenaries, which resulted in liberation of the most of eastern Ukraine from Russian terrorist groups. The isolation ring of the crisis area was narrowed, and units of Russian mercenaries were surrounded and divided into separate cells, creating the preconditions for the full liberation of eastern Ukraine. At that time, the actions of units of the Armed Forces of Ukraine were mostly offensive, in combination with details at checkpoints and raids in certain areas. The main combat unit were battalion tactical groups, operating as assault and raid units. Their backbone were the units of mechanized and high-mobility landing troops, reinforced by tanks, artillery, engineering units with the support of aviation [3, p. 16].

The third stage (25.08 - 5.09.2014) is characterized by the invasion of the Donetsk and Luhansk regions of the regular troops of the Russian army, dramatically changing the combat situation. A large force of one of the groups of Ukrainian troops was surrounded near the town of Illovaisk and broke the encirclement to join the main forces. Gradually, with significant losses, the anti-terrorist operation forces stabilized the line of contact and prevented the advance of Russian occupation troops into the territory of Ukraine [1, p. 32].

During this stage, the main form of troops (forces) employment was the conduct of defensive actions (operations) by operational and tactical groups. In this regard, there was an urgent need for engineering equipment in the area, the construction of defensive lines and positions, implemented by the anti-terrorist operation forces in the future.

Thus, during the first period the form of Russian aggression changed from covert to overt one. This did not allow Ukrainian troops to complete the defeat of IAFs and forced them to enter into open confrontation with the regular troops of the aggressor country, further requiring a change in the forms and methods of their actions.

The second period of the armed conflict (September 5 - April 30, 2014) is divided into five stages.

The fourth stage (September 5, 2014 January 14, 2015) was characterized by a gradual stabilization of the contact line. Regular forces of the so-called "Donetsk People's and Luhansk People's Republics" ("DPR and LPR") were formed from illegal armed formations operating in the occupied territories as a part of the 1st and 2nd Army Corps, which carried out numerous armed 
provocations on the contact line. The leadership and support of these forces was carried out by the Russian Federation.

In order to prevent active offensive actions by the Russian occupation forces, Ukraine began large-scale construction of a defense line along the contact line. At the same time, there was a change in tactics, and the implementation of tasks within the stabilization operation became a feature of the anti-terrorist operation forces employment. Their actions were aimed at maintaining a continuous isolation strip of the crisis area; preventing the expansion of territories controlled by the occupying forces, stopping attempts to penetrate sabotage and reconnaissance groups of the mercenaries into the territories controlled by the Ukrainian authorities. During this time, the brigade units from different directions were united to from one line of defense and the relocate their combat formations for both positional and maneuverable defense while increasing the system of engineering barriers along the entire contact line [3, p. 16].

The fifth stage (January 15 - February 20, 2015) was marked by the repel of the second offensive of the Russian occupation forces. The most important operations of the Armed Forces of Ukraine in eastern Ukraine were the unblocking of army units at the Donetsk airport (18 - 26.01.2015) and the withdrawal of a group of troops from attacks of the Russian occupation forces in the area of Debaltseve (27.01 - 18.02.2015). This group with minimal losses came out from under the attacks of Russians and joined the main forces that moved to contact, captured an important frontier, which further stabilized the situation. Ukrainian troops took a favorable operational position, and the advance of the occupants into the territory of Ukraine was stopped. The goal of the Debaltseve operation was achieved by preventing the encirclement of anti-terrorist operation forces, detaining a strike group of Russian troops trying to reach the flanks of a group of Ukrainian troops, reducing the pace of its offensive, and destroying raid detachments of the Russian army. The main forms of the units' employment were joint actions, combined with territorial defense [4].

During the sixth stage (February 21, 2015 September 20, 2016) the line of defense was strengthened, which in combination with the measures taken for combat training of units and subdivisions of the Armed Forces of Ukraine became an important factor in repelling the offensive of Russian occupation troops near Mariinka in June 2015. In these hostilities, occupation forces' units were defeated, losing a significant number of personnel and equipment. Later, refusing active offensive operations, the Russian occupation forces in Donbas resorted to "tactical actions" in order to deplete and demoralize units of the Armed Forces of Ukraine.

During 2015, in the conditions of a limited number of anti-terrorist operation forces and means, a characteristic feature was the conduct of defense in one echelon on a wide front. The ATO area was reformatted into clearly defined operational and tactical groups with the necessary set of troops, the composition of which was determined depending on the number of dangerous areas. However, the small number of reserve forces did not allow to maneuver forces and means in critical areas and led to the transfer of troops from other areas [3, p. 16]. In 2016, the conditions of the operational situation again led to the transition from maneuver defense, raids and assaults to the tasks of the stabilization operation.

The seventh stage (September 21, 2016 November 2017) is characterized by the separation of forces and means of the parties to the conflict under the decision of the Trilateral Contact Group in Minsk (Republic of Belarus), but around the perimeter of the armed confrontation the enemy concentrated efforts as to advance its unit in depth of socalled "grey zone". The fiercest fighting took 
place in the Avdiivka Industrial Zone (December 2016) and the Svitlodar Arc (December 2016-January 2017), where Ukrainian troops repulsed a series of attacks by Russian occupation forces, exploited success and improved tactics.

For the Armed Forces of Ukraine, the conditions of the operational situation again determined the transition from maneuver defense to the tasks of the stabilization operation. Given this, the emphasis in the tactics of units and subdivisions of the Ukrainian army has changed. They continued to maintain strongholds, focusing their main efforts on securing territory within their areas of responsibility and disrupting communications by the occupying forces.

The eighth stage (November 2017 - April 2018) is characterized by the gradual completion of the anti-terrorist operation. In order to improve the operational and tactical situation in some parts of the contact line with, the key objects were liberated, disrupting important communications of the occupation forces and limiting the maneuver of its reserves. This provided the conditions for future actions by the Ukrainian army in certain operational areas to tactical or operational depth.

On April 30, 2018, the Joint Forces Operation has begun to ensure national security and defense, repel and deter the armed aggression of the Russian Federation in the Donetsk and Luhansk regions. It is being conducted on these territories in special conditions until their release and restoration of the constitutional order [5, p. 28-29].

\section{Conclusions}

The participation of the Armed Forces of Ukraine in the anti-terrorist operation was the result of armed aggression by the Russian Federation. The creation and use by Russian special services of artificially created armed formations, which in a short period of time managed to capture rather large territories in eastern Ukraine, forced the state leadership to use army units. The division of the Russian-Ukrainian armed conflict into periods makes it possible to see that in the first period of the conflict, as a result of active offensive actions of the Armed Forces of Ukraine, illegal armed formations were blocked and doomed to liquidation. To prevent this, the Russian Federation used regular troops, unleashing open aggression against Ukraine. The Armed Forces of Ukraine managed to stop the aggressor's troops and stabilize the contact line. The second period of the antiterrorist operation is characterized by a further increase in the occupation forces' military potential and attempts to penetrate deep into Ukraine, leading to the creation of the Ukrainian line of defense and the transition of the Armed Forces of Ukraine' involved in the anti-terrorist operation, first to defensive and then to stabilization actions.

\section{References List}

[1] White Book of Antiterrorist Operation in the East of Ukraine in 2014-2016, Kyiv, Ministry of Defence of Ukraine. 2017. Available from: https://nuou.org.ua/assets/journals/ bila_knyga/ white-book-ato.pdf

[2] Скрябін О.Л. Збройні Сили України в антитерористичній операції (2014 рік): історико-хронологічний аспект. Воєнно-історичний вісник. №4 (18). 2015. с. 94-98

[3] Баргилевич А.М. Аналіз форм та способів застосування Сухопутних військ Збройних Сил України в антитерористичній операції. Перспективи розвитку озброєння та військової техніки: Збірник тез доповідей Міжнародної науковотехнічної конференції. Львів: НАСВ. 2018. 389 с. 
[4] Analysis of warfare on the Debaltseve ground between 27 January - 18 February 2015. Available from: https:/www.mil.gov.ua/analitichni-materiali/analiz-generalnogoshtabu-zsu-shhodo-bojovih-dij-na-debalczevskomu-placzdarmi-z-27-sichnya-do-18lyutogo-2015-roku.html

[5] Лобко М.М. Деякі аспекти розвитку форм і способів застосування Збройних Сил України для відсічі збройної агресії в сучасних умовах. Збірник наукових пращь Центру воєнно-стратегічних досліджень Начіонального університету оборони України. №1 (68). 2020. с. 26-34 